\title{
The changing clinical pattern of Reye's syndrome 1982-1990
}

\author{
R M Hardie, L H Newton, J C Bruce, J F T Glasgow, A P Mowat, J B P Stephenson, \\ $S$ M Hall
}

\begin{abstract}
Objective-To describe trends in the clinical pattern of Reye's syndrome in the British Isles between 1982 and 1990; and to determine the relation between any changes and the June 1986 warnings against the use of aspirin in children. Design-Development, and application to reported cases, of a scoring system designed such that patients showing the typical clinical and pathological features of 'classical' Reye's syndrome scored highly. The relations between 'Reye scores' and $a$ number of explanatory variables were explored using multivariable analysis.

Setting-British Isles.

Subjects-445 cases fulfilling the Reye's syndrome case definition reported to the surveillance scheme between January 1982 and December 1990.
\end{abstract}

Main outcome measure-Individual 'Reye score'.

Results-Cases with high scores were more likely to have occurred in the $4 \frac{1}{2}$ year period before June 1986 compared with the subsequent period $(p<0 \cdot 006)$. Numbers of cases in the low and intermediate score categories declined by about $50 \%$ after June 1986, whereas those in the high category fell by $79 \%$. High scorers were more likely to have received aspirin $(p<0.0001)$ and were older than intermediate and low scorers $(p<0 \cdot 008)$. No relation was identified between score and season of onset.

Conclusions-The decline in Reye's syndrome after the aspirin warnings cannot be explained entirely, as has been proposed, by improved diagnosis of 'Reyelike' inherited metabolic and other disorders: this would not account for the greater decline of the high scoring subgroup which also contained those cases most likely to resemble 'classical' Reye's syndrome and to have received aspirin. This study provides further evidence for the role of aspirin in a subset of cases meeting the standard diagnostic criteria for Reye's syndrome and supports the need to consider this disorder as a heterogeneous group of conditions including Reye-like inherited metabolic disorders. (Arch Dis Child 1996; 74: 400-405)

Keywords: Reye's syndrome, aspirin, score.

Reye's syndrome is a rare non-inflammatory encephalopathy associated with hepatic dys- function, which principally affects children. There is no unique feature and the diagnosis is based on the combined clinical, biochemical, and histological findings. ${ }^{1}$ Some inherited metabolic disorders mimic Reye's syndrome in all three of these respects ${ }^{2} 3$ and so they satisfy the internationally accepted case definition (given in the box). ${ }^{4}$ This definition has, therefore, increasingly been recognised as nonspecific, ${ }^{5}$ but its practicality and sensitivity mean that it continues to be used for epidemiological surveillance.

\footnotetext{
A child under 16 years with:

1. Unexplained non-inflammatory encephalopathy and one or more of:

2.1 Serum hepatic transaminases elevated $\geqslant 3$ times upper limit of normal

2.2 Plasma ammonia elevated $\geqslant 3$ times upper limit of normal

2.3 Characteristic fatty infiltration of liver
}

The precise pathogenesis of Reye's syndrome has not been established. However, there is a substantial body of laboratory and epidemiological evidence, including six casecontrol studies in the United States, implicating aspirin given during a viral prodrome (typically influenza or varicella). ${ }^{6-16}$ As a result, in 1985 warnings against administration of aspirin to children were issued in the United States.

In the early 1980 s the epidemiological features of Reye's syndrome in the British Isles and in the United States differed. The median age of cases in the United States was 8 to 9 years, compared to 14 months in the British Isles, and only the United States cases showed a winter peak in incidence. ${ }^{1718}$ Nevertheless, a British and Irish case comparison study, carried out in the mid 1980 s, also found an association between Reye's syndrome and aspirin exposure. ${ }^{19}$ Furthermore, using a scoring system in which cases manifesting the most typical features of Reye's syndrome scored highly, a significant correlation between a high 'Reye score' and aspirin exposure was shown. In June 1986, the United Kingdom Committee on Safety of Medicines issued warnings against the use of aspirin in children under 12 years of age. Paediatric aspirin preparations were withdrawn and warning labelling on all aspirin containing preparations was introduced.

In the 1980 s the incidence of reported cases declined in both the United States and the British Isles. ${ }^{18}$ However, controversy about the role of aspirin in the aetiology of Reye's 
syndrome, which began in the early 1980 s, continued. ${ }^{20-26}$ An alternative explanation for the decline was that patients previously misclassified as having Reye's syndrome were now being correctly identified as having the 'Reyelike' inherited metabolic disorders 2426 and were, therefore, not being reported.

Not only have numbers declined in the British Isles, but certain characteristics of cases reported in the period 1981-1991 have changed. Fourteen out of 18 associated with varicella and all 11 with a virologically confirmed influenza prodrome occurred before June 1986; the median age decreased (this has also been observed in the United States ${ }^{5}$ ); and the proportion in whom the diagnosis was subsequently revised increased. ${ }^{18}$

The aim of this study was formally to explore these changes by systematically reviewing the clinical and pathological features of reported cases. We had two hypotheses: first, that patients reported with 'Reye's syndrome' are a heterogeneous group having a number of disorders; second, that these conditions include not only the 'Reye-like' inherited metabolic disorders, but also a separate subgroup in which aspirin ingestion is an aetiological risk factor. We reasoned that the latter may be clinically and epidemiologically distinct from the rest; that they are likely to manifest the features of patients recruited to the American case-control studies ('classical cases': onset in mid to late childhood; peak in winter months; influenza-like or varicella prodrome; profuse vomiting before change in conscious level); and that since mid-1986, when the United Kingdom aspirin warning was issued, it is these cases which selectively declined compared to the rest.

\section{Methods}

Subjects were patients who fulfilled the diagnostic criteria of the case definition (Box) and who were reported by paediatricians to the British Reye's syndrome surveillance scheme, ${ }^{18}$ with onset of illness between 1 January 1982 and 31 December 1990. Thus there were two equal study periods, of $4 \frac{1}{2}$ years each, before and after the June 1986 United Kingdom aspirin warning. Information on each case was derived from medical records only.

We devised a clinical scoring system based on that in an earlier study. ${ }^{19}$ It included not only the features in the case definition, but also those common among patients recruited to the American case-control studies ${ }^{11-17}$ (a distinctive viral prodrome; a clear interval between the onset of the prodrome and onset of encephalopathy; a history of profuse vomiting). Additional relevant variables not consistently available (for example, family history, investigations for inherited metabolic disorders) were included in a free text section of the scoring system. Age, preadmission medication, and date of onset were not included in the score.

Clinical data were coded by two investigators (RMH, LHN). Score sheets with the relevant variables for each patient were sent in random order to a panel of experts (JFTG, APM, JBPS) who independently assigned a 'Reye score' to each case using the predetermined protocol (appendix). The scores ranged from a maximum of 25 (for a case manifesting all the features of 'classical' Reye's syndrome) to a minimum of 1 .

Score sheets differing by 4 points between any two of the three experts (indicating maximum variation in the opinion of the panel of the information in the free text section) were returned to be rescored. The averaged final Reye score for each case was entered on the original record file in the surveillance scheme database.

Those cases in whom the admission diagnosis of Reye's syndrome (leading to a report of a suspected case as requested by the surveillance scheme methodology) had subsequently been revised by the reporting clinician were not scored. This was because for most there was little accompanying clinical information other than the final diagnosis. Their ages and admission dates were, however, usually reported.

\section{ANALYSIS}

Analysis initially carried out in Epi-Info explored the relationship between mean Reye score and the following explanatory variables: age; preadmission medication; onset period (defined as before or after June 1986); year and season of onset.

A preliminary univariate analysis examined the Reye score in its continuous form, whereas for the main analysis the scores were grouped into three categories $(1-12 ; 13-16 ; 17+)$, such that there were approximately equal numbers of cases in each category. This was to observe possible differences in low, intermediate, and high scoring cases. The explanatory variables were also grouped where appropriate (table).

Differences in mean Reye score within each of the explanatory variables were tested using analysis of variance (ANOVA) or KruskalWallis where applicable. Multivariable analysis (to assess the independent effect of each on the score) was performed in GLIM using a Poisson log-linear model for each score category. Two way interactions between variables were assessed to establish whether the effect of any one changed the effect that other variables had on the Reye score.

\section{Results}

Four hundred and forty five cases initially satisfying the case definition were reported 1982-1990. Of these, $91(20 \%)$ subsequently had a revised diagnosis and were therefore not scored. The remaining 354 cases were scored, of whom nine were returned to the panel for rescoring; all then fell within the agreed limit for interobserver variation.

Information on onset date was missing for 22 cases. The figure shows the distribution of the remaining 423 , for each $4 \frac{1}{2}$ year period before compared with after the 1986 aspirin warning. In total, 290 cases occurred in the 
Mean Reye score for each category of explanatory variable

\begin{tabular}{|c|c|c|c|c|}
\hline Variable & $\begin{array}{l}\text { Mean Reye } \\
\text { score }^{\star}(S D)\end{array}$ & $p$ Value $e^{\star \star}$ & $n$ & $\begin{array}{l}\text { Per cent } \\
\text { cases with } \\
\text { revised } \\
\text { diagnosis }\end{array}$ \\
\hline $\begin{array}{l}\text { Age (months) } \\
<12 \\
12-<36 \\
36-<84 \\
84+\end{array}$ & $\begin{array}{l}13 \cdot 9(4 \cdot 5) \\
15 \cdot 3(4 \cdot 2) \\
14 \cdot 6(3 \cdot 1) \\
14 \cdot 5(5 \cdot 0)\end{array}$ & $0 \cdot 1$ & $\begin{array}{r}218 \\
104 \\
53 \\
70\end{array}$ & $\begin{array}{l}27 \cdot 5 \\
26 \cdot 0 \\
18 \cdot 9 \\
12 \cdot 9\end{array}$ \\
\hline $\begin{array}{l}\text { Preadmission med } \\
\text { No drug } \\
\text { Other drug } \\
\text { Aspirin } \\
\text { Not known }\end{array}$ & $\begin{array}{l}\text { cation } \\
13 \cdot 7(3 \cdot 8) \\
15 \cdot 3(3 \cdot 9) \\
17 \cdot 8(3 \cdot 6) \\
12 \cdot 1(4 \cdot 2)\end{array}$ & $<0.0001$ & $\begin{array}{r}81 \\
128 \\
62 \\
174\end{array}$ & $\begin{array}{r}25 \cdot 9 \\
10 \cdot 2 \\
8 \cdot 1 \\
38 \cdot 5\end{array}$ \\
\hline $\begin{array}{l}\text { Onset periodt } \\
\text { Pre June } 1986 \\
\text { Post June } 1986\end{array}$ & $\begin{array}{l}15 \cdot 1(4 \cdot 3) \\
13 \cdot 1(4 \cdot 1)\end{array}$ & $0 \cdot 0005$ & $\begin{array}{l}290 \\
133\end{array}$ & $\begin{array}{l}15 \cdot 9 \\
33 \cdot 8\end{array}$ \\
\hline $\begin{array}{l}\text { Yeart } \\
1982 \\
1983 \\
1984 \\
1985 \\
1986 \\
1987 \\
1988 \\
1989 \\
1990\end{array}$ & $\begin{array}{l}16 \cdot 4(3.9) \\
14.9(4 \cdot 7) \\
14 \cdot 7(4.5) \\
14.5(3.9) \\
14 \cdot 1(4 \cdot 3) \\
13.4(3.8) \\
13.7(4.9) \\
13.6(2 \cdot 7) \\
12 \cdot 1(3.9)\end{array}$ & $0.0002 \ddagger$ & $\begin{array}{l}53 \\
67 \\
90 \\
48 \\
55 \\
38 \\
38 \\
18 \\
16\end{array}$ & $\begin{array}{l}18 \cdot 9 \\
13 \cdot 4 \\
15 \cdot 6 \\
16 \cdot 7 \\
27 \cdot 3 \\
31 \cdot 6 \\
23 \cdot 7 \\
38 \cdot 9 \\
43 \cdot 8\end{array}$ \\
\hline $\begin{array}{c}\text { Month } \\
\text { Jan } \\
\text { Feb } \\
\text { Mar } \\
\text { Apr } \\
\text { May } \\
\text { Jun } \\
\text { Jul } \\
\text { Aug } \\
\text { Sep } \\
\text { Oct } \\
\text { Nov } \\
\text { Dec }\end{array}$ & $\begin{array}{l}12.69(4 \cdot 9) \\
14.57(3 \cdot 9) \\
15 \cdot 64(4 \cdot 1) \\
13 \cdot 28(4 \cdot 5) \\
14 \cdot 14(4 \cdot 4) \\
14 \cdot 49(4 \cdot 7) \\
13 \cdot 44(5 \cdot 2) \\
14.37(4 \cdot 2) \\
15 \cdot 32(4 \cdot 0) \\
15 \cdot 69(4 \cdot 3) \\
14 \cdot 52(4 \cdot 0) \\
14 \cdot 78(4 \cdot 2)\end{array}$ & $0 \cdot 16$ & $\begin{array}{l}60 \\
44 \\
43 \\
36 \\
27 \\
29 \\
30 \\
22 \\
24 \\
45 \\
42 \\
43\end{array}$ & $\begin{array}{l}41 \cdot 7 \\
11 \cdot 4 \\
25 \cdot 6 \\
30 \cdot 6 \\
18 \cdot 5 \\
17 \cdot 2 \\
23 \cdot 3 \\
18 \cdot 2 \\
16 \cdot 7 \\
20 \cdot 0 \\
19 \cdot 0 \\
27 \cdot 9\end{array}$ \\
\hline
\end{tabular}

${ }_{\star}^{\star}$ Mean Reye score (excludes cases with a revised diagnosis). $\star \star$ Kruskal-Wallis on difference of means.

†There were 22 cases with unknown onset.

$\ddagger$ Test for linear trend.

first period and 133 in the second. There were almost equal numbers of revised diagnosis cases in each period: $46(16 \%$ total that period) and $45(34 \%)$ respectively. The marked increase in the proportion of these cases was due to the decline in all other categories except this one after June 1986. The corresponding figures for the low and intermediate score groups were $68(23 \%)$ and 74 $(26 \%)$ before the warning, and $35(26 \%)$ and $32(24 \%)$ after the warning. Among the highest scoring group (17-25) there were 102 prewarning (35\% total that period) and $21(16 \%)$ postwarning. Only two of 28 cases scoring 21-25 occurred after June 1986.

The results of preliminary univariate analysis of the association between mean Reye score and the explanatory variables are shown in the table. Overall, the differences in mean Reye score between categories of preadmission medication (no drug, aspirin, other drug, not known) were highly significant $(p<0.0001)$. A significantly higher mean Reye score $(17 \cdot 8)$ was observed for cases with a reported exposure to aspirin compared with that $(15 \cdot 3)$ for exposure to other drugs $(p=0.003)$ and that (13.7) for no drug $(\mathrm{p}<0.001)$. Ten per cent $(7 / 68), 10 \%(7 / 74)$, and $37 \%(38 / 102)$ of cases scoring 1-12, 13-16, and $17+$ respectively had a reported history of aspirin exposure before June 1986. The corresponding figures after the warning were $0,6 \%(2 / 32)$, and $14 \%(3 / 21)$.

As expected from the data shown in the figure, a significantly higher mean Reye score was also observed for cases occurring before
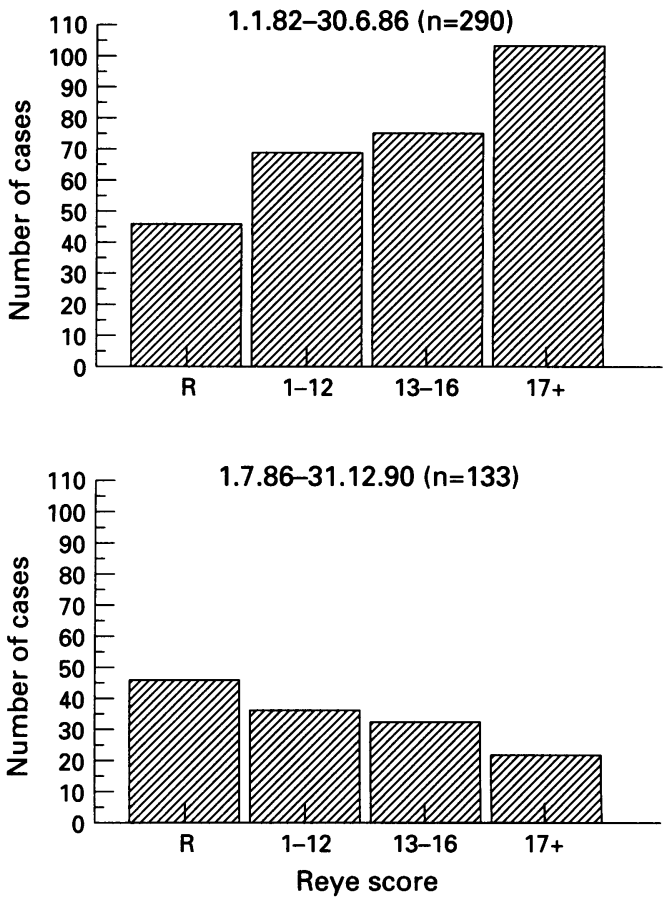

Distribution of cases within 'Reye score' groups before and after the mid-1986 aspirin warning.

$(15 \cdot 1)$ rather than after (13.1) the aspirin warning $(p=0.0005)$. Moreover, a decreasing trend in mean score was observed from 1982 to $1990(p=0.0002)$. There was a suggestion of an age effect with children under one year having the lowest mean score, although this did not achieve statistical significance $(p=0 \cdot 1)$. There was no indication of significant difference in mean score by month of onset $(\mathrm{p}=0 \cdot 16)$.

The multivariable analysis showed a significant independent relationship between Reye score and the following: onset period (highest scores before mid 1986, $\mathrm{p}<0.006$ ); age (score increased with age, $\mathrm{p}<0 \cdot 008$ ), and preadmission medication (highest scores associated with preadmission aspirin, $p<0.0001)$. There was no indication of a relation between score and season of onset $(p=0 \cdot 23)$.

Information on preadmission medication exposure was provided in nearly all cases in the highest score category, compared to under $50 \%$ of score category $1-12$, and the revised diagnosis cases. Such differential recording of preadmission medication exposure may have been a source of bias, with clinicians perhaps being less likely to take a medication history if they were not convinced of the diagnosis of Reye's syndrome. However, the model developed to examine the relations between the key variables and Reye score was not significantly different when cases with unknown preadmission medication history were included or excluded.

Examination of interactions between the variables showed only one: onset period and season. This suggested that the seasonal distribution of cases differed before, compared with after, the aspirin warning. However, this evidence was not strong enough to justify adjusting for these differences in the model $(p=0.06)$. Thus, after allowing for confounding and interaction, these 
analyses suggested that there were three independent determinants of Reye score: age; preadmission medication; and onset before or after mid-1986.

\section{Discussion}

In this study we aimed to determine whether there was a change in the pattern of Reye's syndrome between 1982 and 1990, and if so to explore reasons for that change by innovative use of existing surveillance data.

We devised a scoring system using objective criteria to allocate each patient a place on a spectrum of disease ranging from 'non-classical' (low scorers) to 'classical' (high scorers) Reye's syndrome. The latter resembled patients reported to the United States Reye's syndrome surveillance scheme in the 1970s and early 1980s and those recruited to the case-control studies in that country. ${ }^{511-17}$ The intermediate and low scorers may have included some cases of Reye's syndrome, but we surmised that these patients were more likely to have a range of undiagnosed 'Reyelike' disorders. ${ }^{1-3}$ 27-29

Two other studies retrospectively reviewed the medical records of patients with an admission $^{4}$ or discharge ${ }^{28}$ diagnosis of 'Reye's syndrome' to assess the likelihood that some of them had been misdiagnosed. Both studies, like ours, used an expert panel. Although one specified a number of criteria to classify cases as 'certain', 'probable', 'unlikely', or 'excluded', ${ }^{28}$ neither used a scoring system.

The expert panels in the two other studies concluded that one third ${ }^{4}$ and three quarters ${ }^{28}$ of their cases definitely or probably did not have Reye's syndrome, and that $30 \%$ and $28 \%$ respectively could only be assigned as 'uncertain' or 'probable'. In our study, the wide distribution of scores suggested that reported cases of Reye's syndrome were a clinically heterogeneous group. This heterogeneity emphasises the need to regard 'Reye's syndrome' as consisting of a number of conditions, including inherited metabolic disorders, and to consider suspected patients as having a 'Reye-like disorder' until alternative diagnoses have been excluded. ${ }^{2}$ If our scoring system is a valid predictor of 'Reye' versus 'Reye-like' then the patients with revised diagnoses should have had low scores. Unfortunately, the lack of systematically collected clinical information in this group, inherent in the surveillance system methodology, precluded such an analysis. It could, however, easily be undertaken by referral centres with large series of such cases.

Multivariable analysis indicated that our high scoring cases tended to be older. This is consistent with the epidemiological picture of Reye's syndrome in the United States in the 1970s and early 1980s. Furthermore each of the other studies found that their 'definite' and 'probable' cases were significantly older than those categorised as 'uncertain' and 'definitely not' Reye's syndrome. ${ }^{428}$

One explanation for the observed association between age and Reye score groups is that the 'non-classical', low scoring cases may have had unrecognised inherited Reye-like metabolic disorders. These involve absence or low activity of individual enzymes in key steps in the urea cycle or fatty acid oxidation pathways. Although they may rarely manifest at older ages, they are most likely to present in infants and young children. ${ }^{2-4}$ The association between high scoring groups and older age is consistent with classical Reye's syndrome, being related to factors other than deficiency of a single enzyme.

We did not find an association between Reye score and season of onset. The classical United States cases typically occurred most frequently in winter in association with influenza outbreaks. There were no major influenza epidemics in the United Kingdom between 1982 and 1990 (although there was moderate activity in the winter of $1989 / 90$ ), which may account for our finding. It was, however, of interest that the seasonal distribution of cases changed in the second study period, although this trend did not quite achieve statistical significance.

The highest scoring patients were also those most likely to have been exposed to preadmission aspirin and to have occurred before June 1986. These two risk factors were independent of each other and of age. Overall, however, only $33 \%$ of highest scoring patients were reported as having had aspirin. This compares with over $90 \%$ of cases in the American casecontrol studies and $59 \%$ in the United Kingdom risk factor study. ${ }^{11-16} 19$ There are three possible explanations: first, the data on aspirin exposure in our study were abstracted by the reporting clinician from medical records and were therefore less reliable than the parental interviews of the case-control studies ${ }^{19}$; second, even these high scoring cases may have been diluted by 'non-classical' Reye's syndrome patients, since the score band used in the analysis (17-25) was relatively wide. If it is narrowed, $50 \%$ of cases scoring 21-25 (14/28) had a reported history of aspirin exposure, compared to none of eight scoring 1-5. Finally, not all cases, even of classical Reye's syndrome, may be aspirin associated.

We observed a decline in absolute numbers of cases within each of the score groups in the second $4 \frac{1}{2}$ year study period compared to the first. However, the downward trends in the low and intermediate score groups (by $41 \%$ and $57 \%$ respectively) were substantially smaller than that in the high scorers $(79 \%)$. The decline in low and intermediate scorers is consistent with our suggestion that these groups contained patients with undiagnosed Reye-like inherited metabolic and other disorders and with speculation that, in recent years, such patients have been the subject of earlier and more precise laboratory diagnosis and may not, therefore, be reported as Reye's syndrome. ${ }^{24-26}$

This alternative explanation for the falling incidence of the syndrome (as against the effect of aspirin warnings) does not, however, explain the significantly greater decline in the subset of patients who most resemble classical Reye's syndrome. If this notion were correct, our 
score categories should either have declined at equal rates, or low scoring cases should have shown the greater decline. Furthermore, detailed investigation of classical cases of Reye's syndrome has not revealed any inherited metabolic disorders (Glasgow JFT, unpublished data, and ${ }^{29}$ ) and by virtue of their older age they are the least likely group to have such disorders. It was noteworthy too that the numbers of revised diagnosis cases were almost identical in each study period even though the reporting criteria did not change between 1982 and 1990.

We conclude that, within the overall decline in reported cases of Reye's syndrome, there was a significantly greater reduction in high scoring ('classical') cases, compared to lower scoring patients, after June 1986. The former were also older and more likely to have had preadmission aspirin. We believe that these observations support our hypothesis that,

Appendix

One score to be selected from each section $A$ to I

\begin{tabular}{|c|c|c|c|}
\hline \multicolumn{2}{|c|}{ Feature } & \multirow{2}{*}{$\begin{array}{l}\text { Response } \\
\text { Yes, varicella/flu like } \\
\text { Yes, other prodrome } \\
\text { Not recorded } \\
\text { No prodrome }\end{array}$} & \multirow{2}{*}{$\begin{array}{l}\text { Score } \\
3 \\
2 \\
1 \\
0\end{array}$} \\
\hline $\mathbf{A}$ & $\begin{array}{l}\text { Clearly defined prodrome } \\
\text { A prodrome which is varicella/flu like } \\
\text { takes preference over another category }\end{array}$ & & \\
\hline $\mathbf{B}$ & $\begin{array}{l}\text { Interval(s) between date of onset } \\
\text { of prodrome and date of } \\
\text { admission/onset } \\
\text { Smaller interval takes preference }\end{array}$ & $\begin{array}{l}\text { 1-7 days } \\
\text { Date of prodrome not recorded } \\
\text { No prodrome } / 0 \text { days } />3 \text { weeks }\end{array}$ & $\begin{array}{l}3 \\
2 \\
1 \\
0\end{array}$ \\
\hline C & Vomiting & $\begin{array}{l}\text { Moderate-severe } \\
\text { Minimal/severity not recorded } \\
\text { Vomiting not recorded } \\
\text { No vomiting }\end{array}$ & $\begin{array}{l}4 \\
2 \\
1 \\
0\end{array}$ \\
\hline $\mathbf{D}$ & $\begin{array}{l}\text { Serum alanine or aspartate } \\
\text { transaminase }\end{array}$ & $\begin{array}{l}\text { Level }>\text { or }=100 \\
\text { Level } 40-99 \text { or just 'raised' } \\
\text { Not measured/not recorded } \\
\text { Not raised }\end{array}$ & $\begin{array}{l}3 \\
2 \\
1 \\
0\end{array}$ \\
\hline $\mathbf{E}$ & Ammonia & $\begin{array}{l}\text { Level }>\text { or }=150 \\
\text { Level } 50-149 \text { or just 'raised' } \\
\text { Not measured/not recorded } \\
\text { Not raised }\end{array}$ & $\begin{array}{l}3 \\
2 \\
1 \\
0\end{array}$ \\
\hline $\mathbf{F}$ & Prothrombin time & $\begin{array}{l}\text { INR } \geqslant 2 \cdot 0 \\
\text { INR not recorded } \\
\text { INR }<2 \cdot 0\end{array}$ & $\begin{array}{l}2 \\
1 \\
0\end{array}$ \\
\hline $\mathbf{G}$ & Cerebrospinal fluid & $\begin{array}{l}\text { White cell count normal } \\
\text { White cell count not examined/not } \\
\text { recorded } \\
\text { White cell count abnormal }\end{array}$ & $\begin{array}{l}2 \\
1 \\
0\end{array}$ \\
\hline $\mathbf{H}$ & $\begin{array}{l}\text { Hepatic pathology } \\
\text { Histological result is scored in } \\
\text { preference }\end{array}$ & $\begin{array}{l}\text { Histology consistent with Reye's } \\
\text { Syndrome } \\
\text { Histology not consistent } \\
\text { Macroscopically fatty/enlarged/yellow } \\
\text { and no histology recorded } \\
\text { No information or normal } \\
\text { macroscopically only }\end{array}$ & $\begin{array}{l}3 \\
0 \\
2 \\
1\end{array}$ \\
\hline $\mathbf{I}$ & \multicolumn{2}{|c|}{ Comments: A free text section detailing only the following: } & $\begin{array}{l}\text { verall } \\
\text { to }+2\end{array}$ \\
\hline & $\begin{array}{l}\text { vestigations (irrespective of results, } \\
\text { ich will be specified) to exclude: }\end{array}$ & $\begin{array}{l}\text { - Inborn errors of metabolism } \\
\text { Poisoning (excluding any mention of } \\
\text { salicylate level investigation unless } \\
\text { aspirin overdose was a diagnostic } \\
\text { possibility) } \\
\text { - Systemic infection } \\
\text { - Alternative liver function tests: } \\
\text { - alkaline phosphatase } \\
\text { - } \gamma \text { glutamyl transferase } \\
\text { - Liver electron microscopy and } \\
\text { histochemistry results }\end{array}$ & \\
\hline & ypical features: & $\begin{array}{l}\text { Rapid improvement in conscious level } \\
\text { with intravenous glucose } \\
\text { Clinical jaundice or raised serum } \\
\text { bilirubin (value will be given if known) } \\
\text { Histology if not consistent with Reye's } \\
\text { syndrome (see H) }\end{array}$ & \\
\hline & $\begin{array}{l}\text { st medical history and } \\
\text { mily history of case: }\end{array}$ & $\begin{array}{l}\text { All of patient's details recorded in } \\
\text { source material }\end{array}$ & \\
\hline
\end{tabular}

If information in one of these categories is not detailed here then it was not provided in the original case description. within the heterogeneity of conditions encompassed by the diagnostic criteria of 'Reye's syndrome', there is a subset which is aetiologically associated with aspirin ingestion. The findings of a recent French study support our argument: a series of patients admitted with Reyelike illnesses was extensively investigated for inherited metabolic disorders. ${ }^{30}$ Those with negative findings were significantly more likely to have had aspirin than those in whom such a disorder was found.

Our scoring system could be useful if included in a continuing epidemiological surveillance system for Reye's syndrome. It would enable early detection of an increase in cases with high scores, indicating a possible need to re-emphasise aspirin warnings, especially during an influenza epidemic.

Although we have surmised that the lower the score the more likely is an inherited metabolic disorder, these conditions must always be included in the differential diagnosis of all 'Reye-like' illnesses. This is especially important in very young patients, but ideally those at all ages should be intensively investigated. ${ }^{1-4}$ 26-30 Preadmission medication exposure should not influence diagnosis in either direction. Until its aetiopathogenesis is fully elucidated, it would be unwise to assume that all cases, even of 'classical' Reye's syndrome, were aspirin associated.

We thank all paediatricians who reported cases and completed proformas. Without their help this study would not have been possible. We acknowledge the generous support given to the British Paediatric Association Surveillance Unit (through which surveillance of Reye's syndrome is conducted) by the Medical Research Fund of Children Nationwide. JFTG would like to acknowledge the continuing generous support of the National Reye's Syndrome Foundation of the United Kingdom.

1 Glasgow JFT, Moore R. Reye's syndrome 30 years on. BMY 1993; 307: 950-1.

2 Green A, Hall SM. Investigation of metabolic disorders resembling Reye's syndrome. Arch Dis Child 1992; 67: 1313-7.

3 Rowe PC, Valle D, Brusilow SW. Inborn errors of metabolism in children referred with Reye's syndrome. $\mathfrak{F} A M A$ 1988; 260: 3167-70.

4 Forsyth BW, Shapiro ED, Horwitz RI, Viscoli CM, Acampora D. Misdiagnosis of Reye's-like illness. Am $\mathcal{f} D$ is Child 1991; 145: 964-6.

5 Hurwitz ES. The changing epidemiology of Reye's syndrome in the United States: further evidence for a public health success. FAMA 1988; 260: 3178-9.

6 Rodgers GC. Analgesics and Reye's syndrome: fact or fiction? In: Pollack JD, ed. Reye's syndrome IV. Bryan, Ohio: National Reye's Syndrome Foundation, 1985:117-34.

7 Partin JS, Daugherty CC, McAdams AJ, Partin JC, Schubert WK. A comparison of liver ultrastructure in salicylate intoxication and Reye's syndrome. Hepatology 1984; 4: 687-90.

8 Martens ME, Lee C. Reye's syndrome: salicylates and mitochondrial functions. Biochem Pharmacol 1984; 33: 2869-76.

9 Faraj BJ, Caplan D, Lolies P. Buchanan C. Salicylate and mitochondrial monoamine oxidase function in Reye's syndrome. F Pharm Sci 1987; 76: 423-6.

10 Trauner DA, Horvath E, Davis LE. Inhibition of fatty acid oxidation by influenza $B$ virus and salicylic acid in mice: implications for Reye's syndrome. Neurology 1988; 38: 239-41.

11 Starko KM, Ray CG, Dominguez LB, Stromberg WL, Woodall DF. Reye's syndrome and salicylate use. Pediatrics 1980; 66: 859-64.

12 Halpin TJ, Holtzhauer FJ, Campbell RJ, et al. Reye's syndrome and medication use. FAMA 1982; 248: 687-91.

13 Waldman RJ, Hall WN, McGee H, Van Amburg G. Aspirin as a risk factor in Reye's syndrome. $\mathcal{F} A M A$ 1982; 247: as a risk $3089-94$.

14 Hurwitz ES, Barrett, MJ, Bregman D, et al. Public Health Service study on Reye's syndrome and medications. Report of

15 Hurwitz ES, Barrett MJ, Bregman D, et al. Public Health Service study of Reye's syndrome and medications. fAMA 1987; 257: 1905-11. 
16 Forsyth CW, Horwitz RI, Acampora D, et al. New epidemiological evidence confirming that bias does not explain the aspirin/Reye's syndrome association. $¥ A M A$ 1989; 261: 2517-24.

17 Hurwitz ES. Reye's syndrome. Epidemiol Rev 1989; 11: 249-53.

18 Newton L, Hall SM. Reye's syndrome in the British Isles: report for 1990/91 and the first decade of surveillance. remmunic Dis Rep 1993; 3: R11-16.

19 Hall SM, Plaster PA, Glasgow JFT, Hancock P. Preadmission antipyretics in Reye's syndrome. Arch Dis Child 1988; 63: 857-66.

20 Reye's Syndrome Working Group, Aspirin Foundation of America. Reye's syndrome and salicylates: a spurious association. Pediatrics 1982; 70: 158-60.

21 Daniels SR, Greenberg RS, Ibrahim MA. Scientific uncertainties in the studies of salicylate use and Reye's syndrome. $\mathscr{f} A M A$ 1983; 249: $1311-6$.

22 Orlowski JP, Gillis J, Kilham HA. A catch in the Reye. Pediatrics 1987; 80: 638-42.

23 Orlowski J, Campbell P, Goldstein S. Reye's syndrome: case control study of medication use and associated viruses in Australia. Cleveland Clinic $\mathcal{F}$ Med 1990; 57: 323-9.
24 Casteels-van Daele $M$. Reduction of deaths after drug abelling for risk of Reye's syndrome. Lancet 1993; 341: 118-9.

25 Khan AS, Kent J, Schonberger LB. Aspirin and Reye's syndrome. Lancet 1993; 341: 968.

26 Casteels-van Daele, Eggermont E. Reye's syndrome. BMF 1994; 308: 919-20.

27 Partin JS. Ultrastructural changes in liver, muscle and brain in Reye's syndrome. In: Wood C, ed. Reye's syndrome. in Reye's syndrome. In: Wood C, ed. Reye's syndrome. Leries No 8, 1986: 1-19.

28 Gauthier M, Guay J, Lacroix J, Lortie A. Reye's syndrome: a reappraisal of diagnosis in 49 presumptive cases. $A m \mathcal{F}$ Dis Child 1989; 143: 1181-5.

29 Roe CR. Metabolic disorders producing a Reye-like syndrome. In: Wood C, ed. Reye's syndrome. London: Royal Society of Medicine Services Round Table Series No 8, 1986: 85-107.

30 De Villemeur TB, Nuttin C, Poggi F, et al. Metabolic investigations in Reye's syndrome and Reye-like syndrome. In: Buts JP, Sokal EM, eds. Management of digestive and liver disorders in infants and children. Amsterdam: Elsevier, 